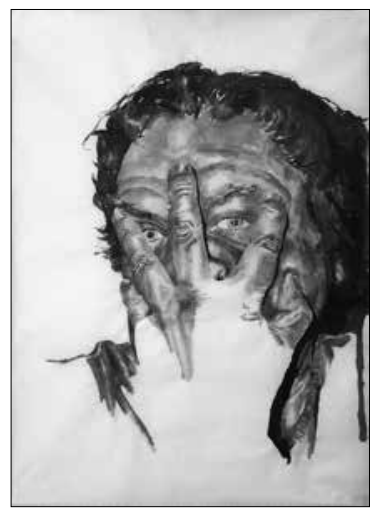

\title{
DAILININKAS RIMVYDAS MULEVIČIUS
}

Rimvydas MULEVIČıUS gimė 1957 m. Vilniuje. Jaunystejje būsimasis menininkas dirbo tuometiniame Vilniaus valstybiniame dramos teatre scenos montuotoju, vèliau - dailininku dekoratoriumi ir butaforu. Kūrybinèje teatro atmosferoje pajuto, kad tolesnis jo gyvenimo kelias turètų sietis su menu. Tad $1980 \mathrm{~m}$. ìstojo ị Vilniaus dailès institutą (dab. Vilniaus dailès akademiją), kur Monumentaliosios tapybos katedroje 1986 m. baigè vitražo specialybę. Po studijų R. Mulevičius buvo paskirtas dèstytoju i VDA Kauno fakultetą, kuriame dirba jau daugiau kaip trisdešimt metų, vadovauja Piešimo studijai, yra šios studijos profesorius.

Keletą dešimtmečių dailininko pagrindiniu raiškos objektu buvo vitražas. Autorius yra igyvendinęs keliolika monumentalių darbų visuomeniniuose ir privačiuose interjeruose, vitražais papuošęs ne vieną bažnyčią. Tačiau pastaraisiais metais R. Mulevičius daugiausia kuria akvarelès, grafikos ir piešinio darbus, dalyvauja šių meno sričių jungtiniuose projektuose, rengia personalines parodas Lietuvoje ir užsienyje. Taip pat profesorius garsèja kaip originalus edukatorius, piešinio kaip savitos kūrybinės raiškos propaguotojas, studentų piešimo projektų organizatorius.

\section{Artist Rimvydas Mulevičius}

Rimvydas MULEVIČIUS was born in 1957 in Vilnius. In his young years, The artist worked in the formerly named Vilnius National Drama Theatre as a scene assembler, an artist-decorator and a prop designer. Under the influence of the creative atmosphere in the theatre, R. Mulevičius decided that his life should be related to art. Therefore, in 1980 he entered the Vilnius Art Institute (now Vilnius Art Academy), where in 1986 he graduated in stained-glass, specialty in the Monumental painting department. After the studies, R. Mulevičius was employed in the Vilnius Art Academy Kaunas faculty to work in the position of a lecturer. Here he has been working for over 30 years. He also became the head and professor of the Drawing studio.

| R. Mulevičius. Autoportretas. Tapyba kinišku tušu

RAKTAŽODŽlAI: R. Mulevičius, piešinys, grafika, akvarelè, vitražas

KEY WORDS: R. Mulevičius, drawing, graphic, watercolour, stained-glass. 
For a few decades, his key object of expression was stained-glass. The author produced over ten monumental works in public and private interiors; he also decorated some churches. However, in the recent years, R. Mulevičius mostly creates in the areas of watercolour, graphics and drawing. He also participates in projects of the previously mentioned fields, organizes personal exhibitions in Lithuania and abroad. Furthermore, the professor is known as an original educator, propagator of drawing as a distinctive mean of expression, and organizer of students' drawing projects.

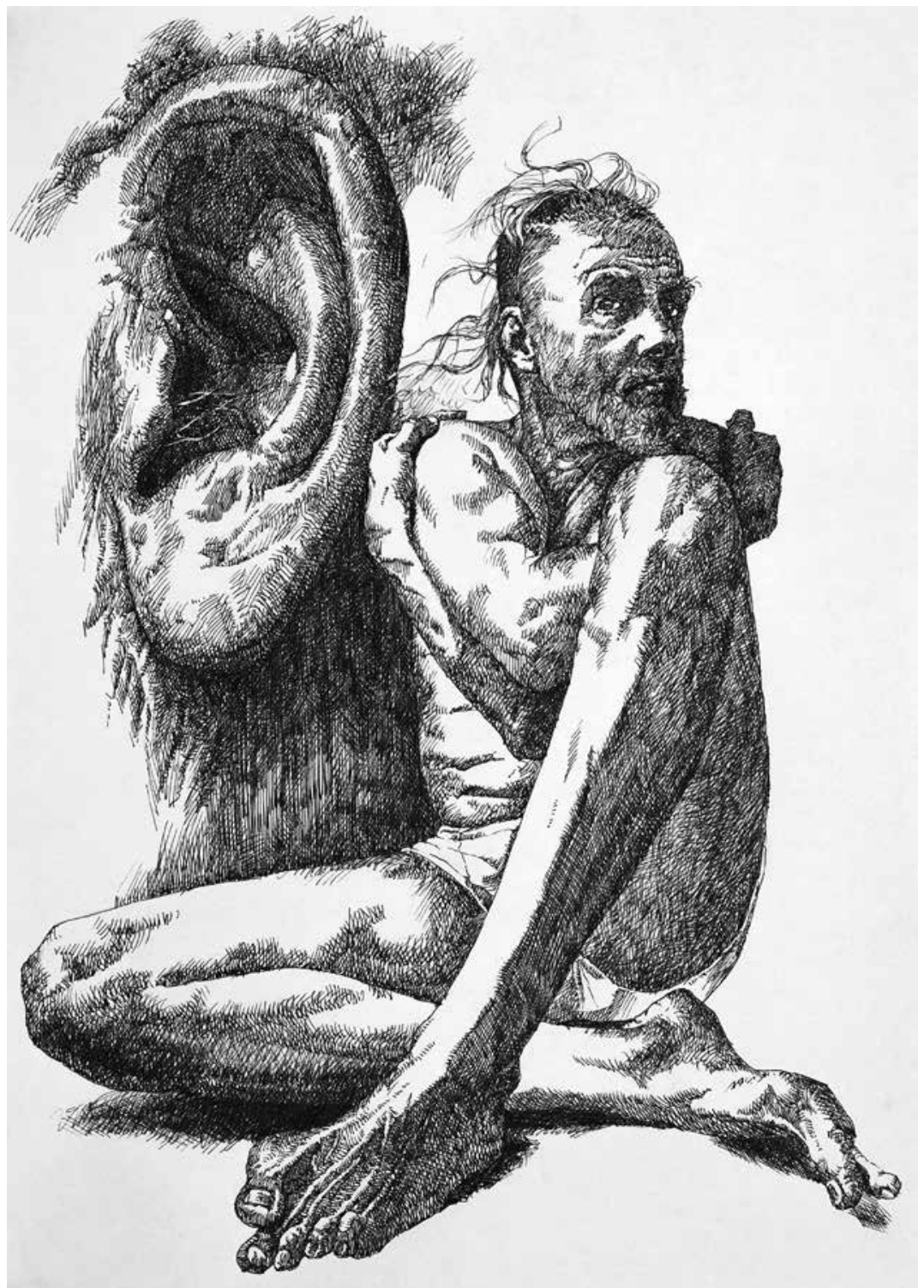

R. MULEVIČIUS. Gandas. Estampas 


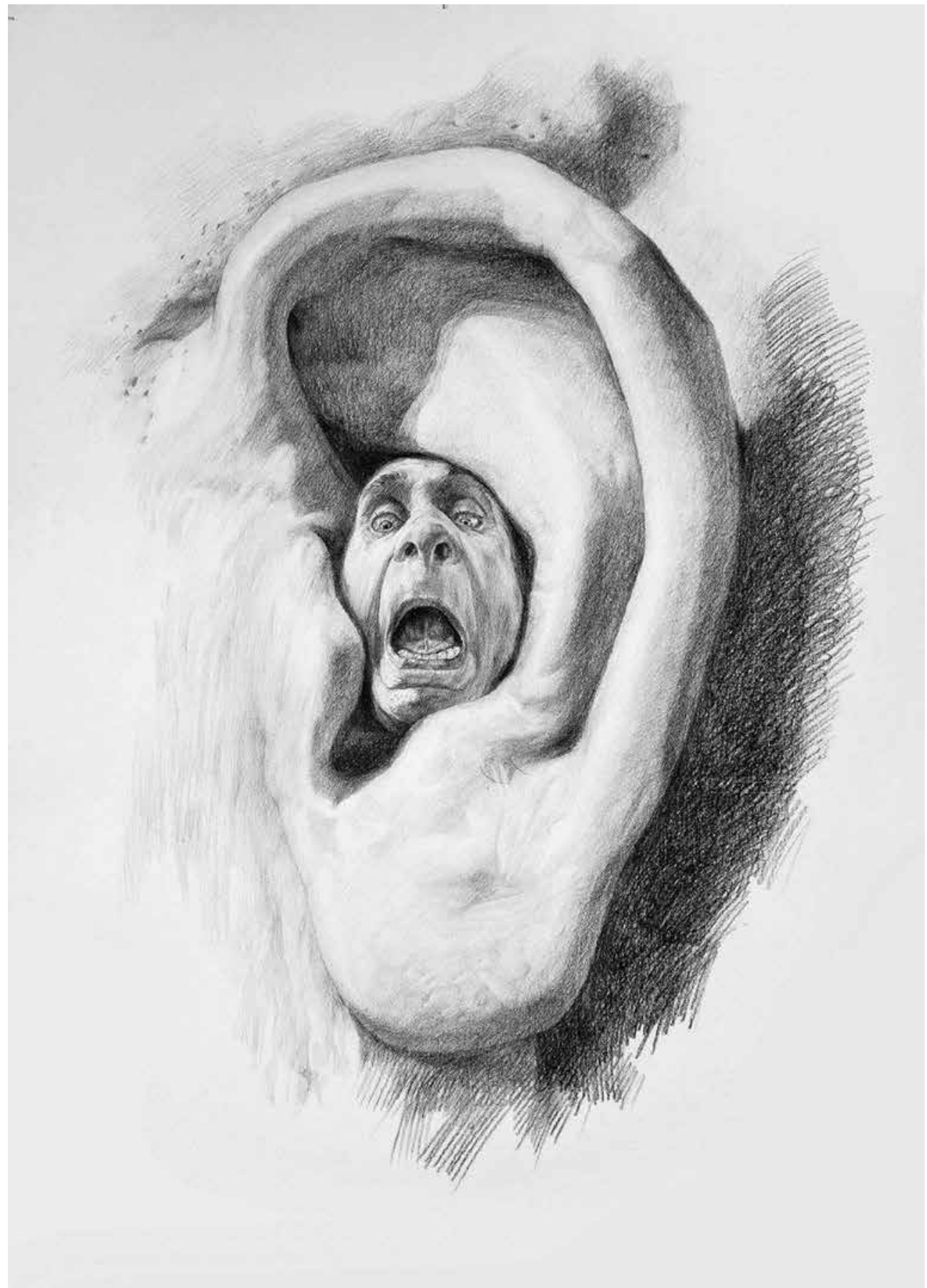

R. MULEVIČIUS. Fama (gandas) III. Piešinys (triptikas 3) 


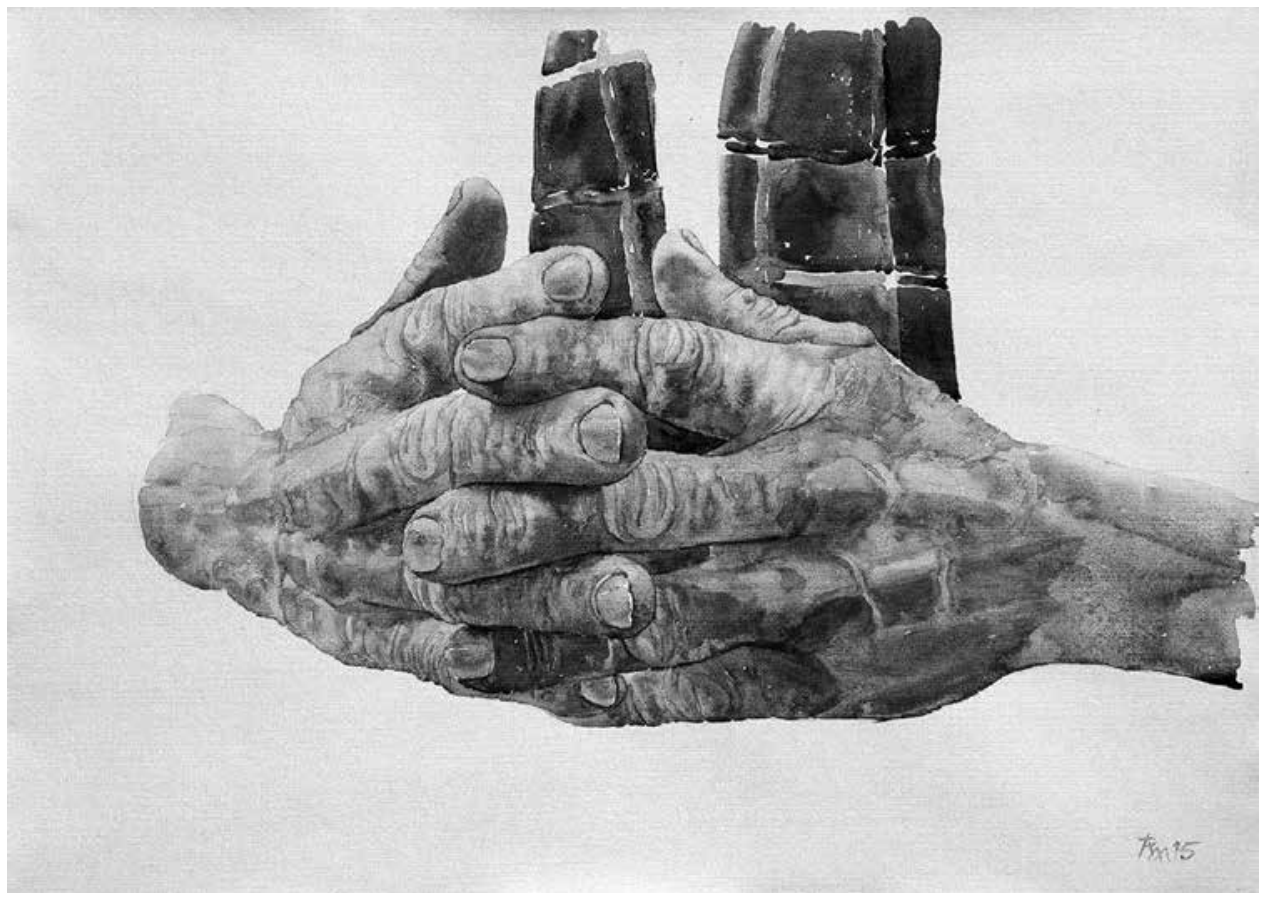

R. MULEVIČIUS. Malda I. Akvarelè (triptikas 1)

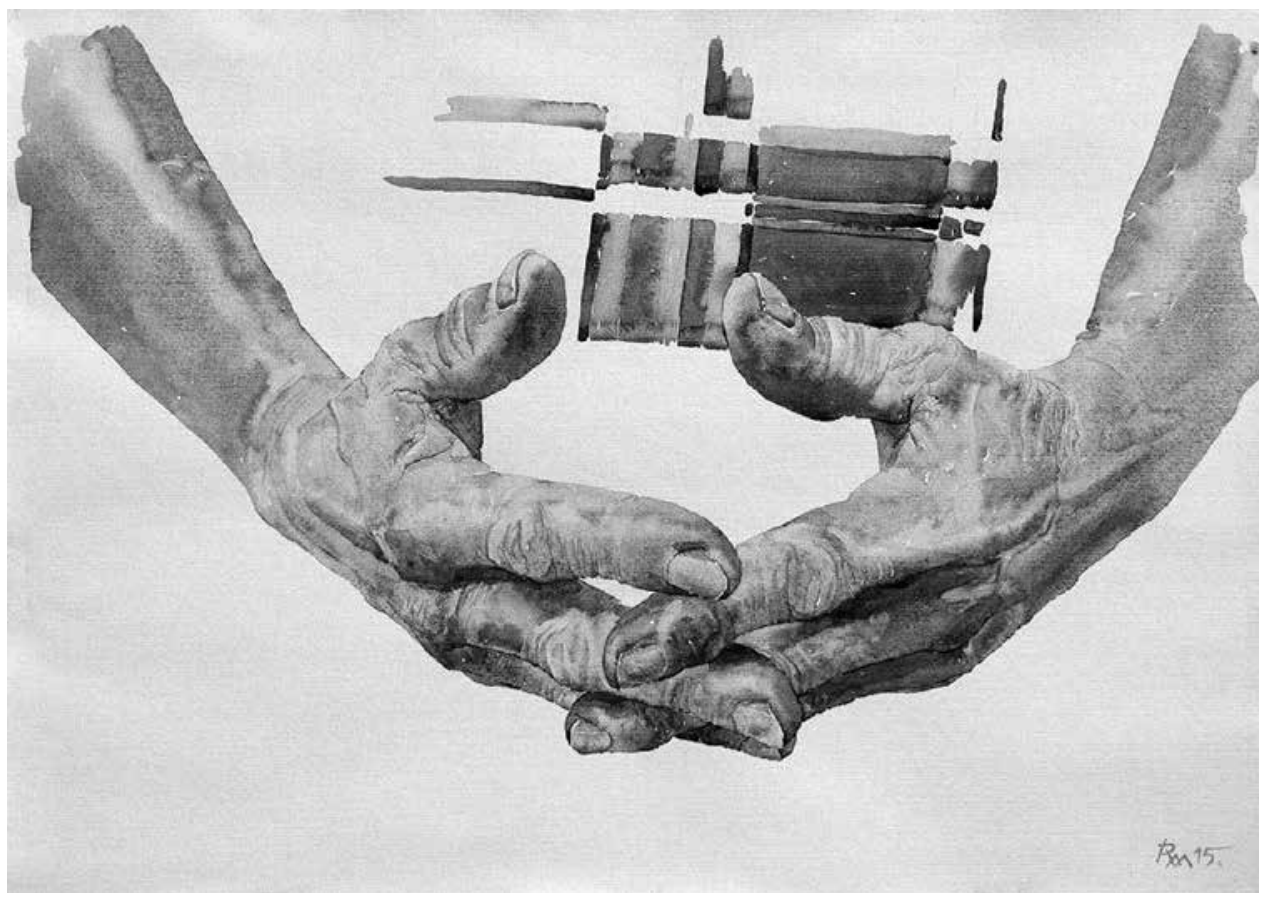

R. MULEVIČIUS. Malda II. Akvarelè (triptikas 2) 


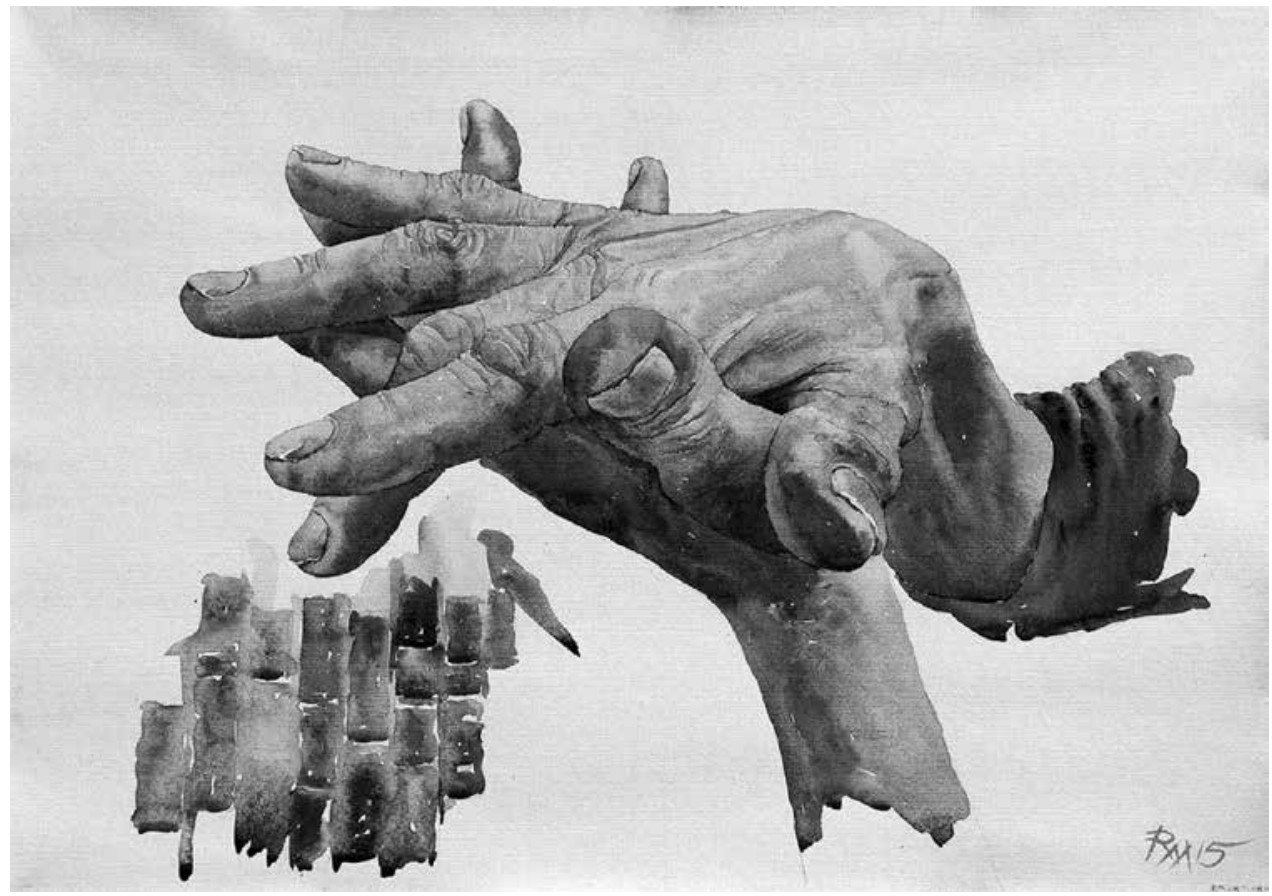

R. MULEVIČIUS. Malda III. Akvarelè (triptikas 3)

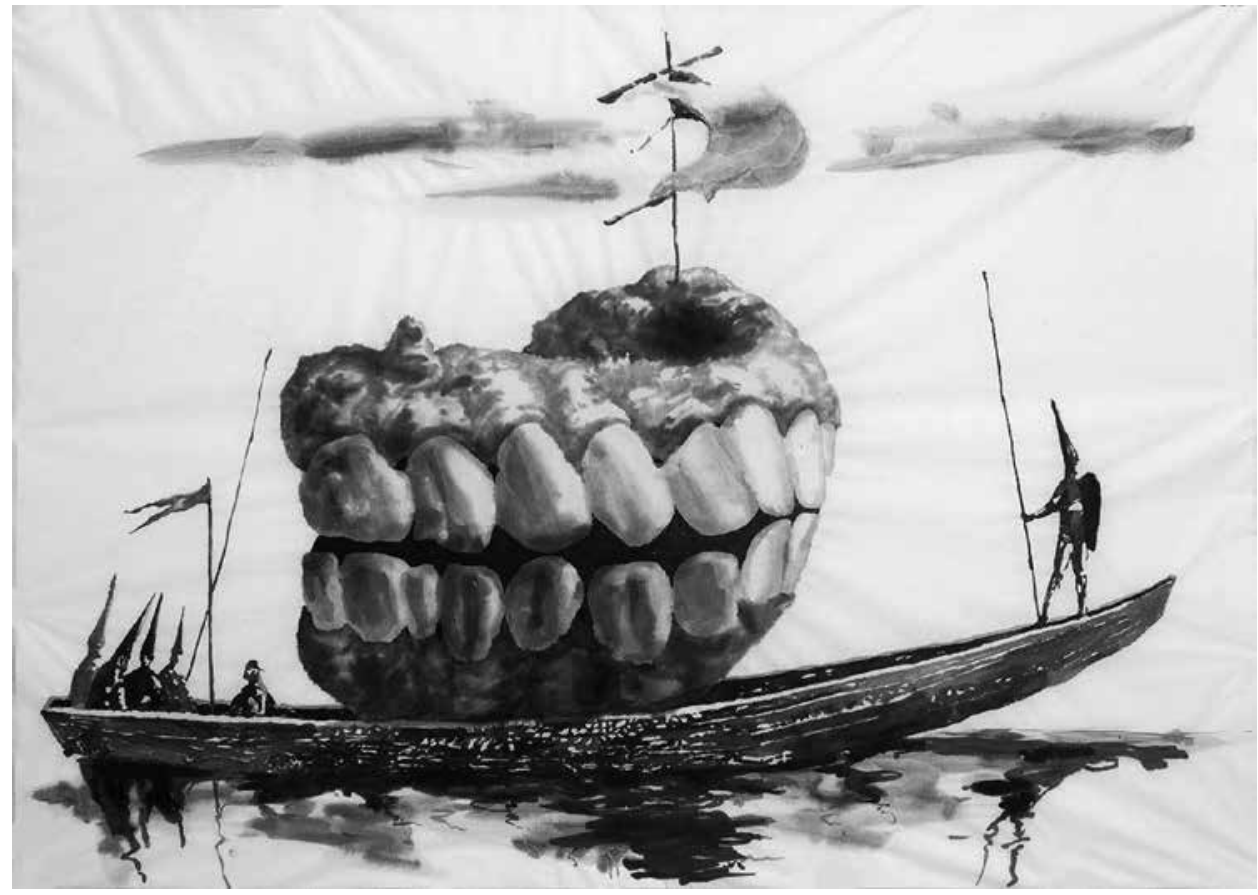

R. MULEVIČIUS. Kelionė. Tapyba kinišku tušu 


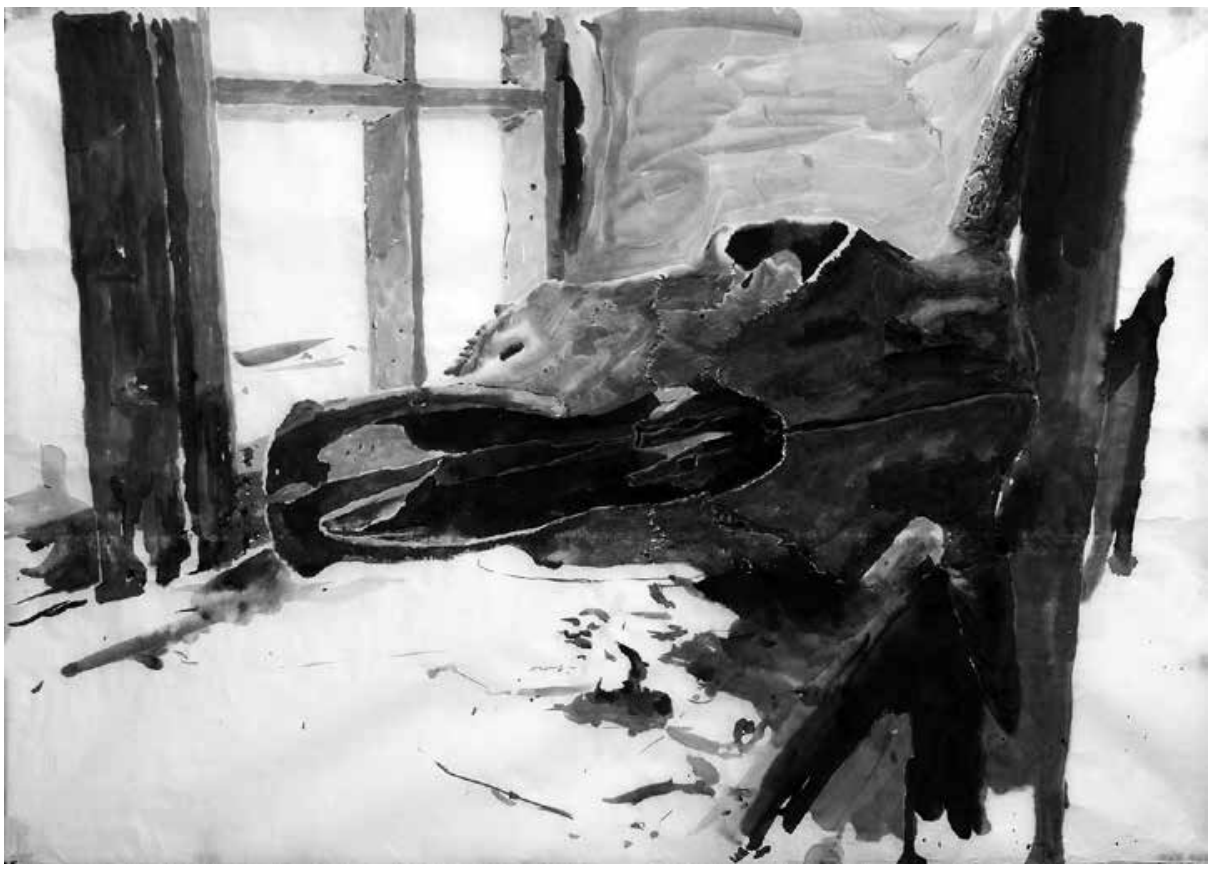

R. MULEVIČIUS. Kaukolè. Tapyba kinišku tušu

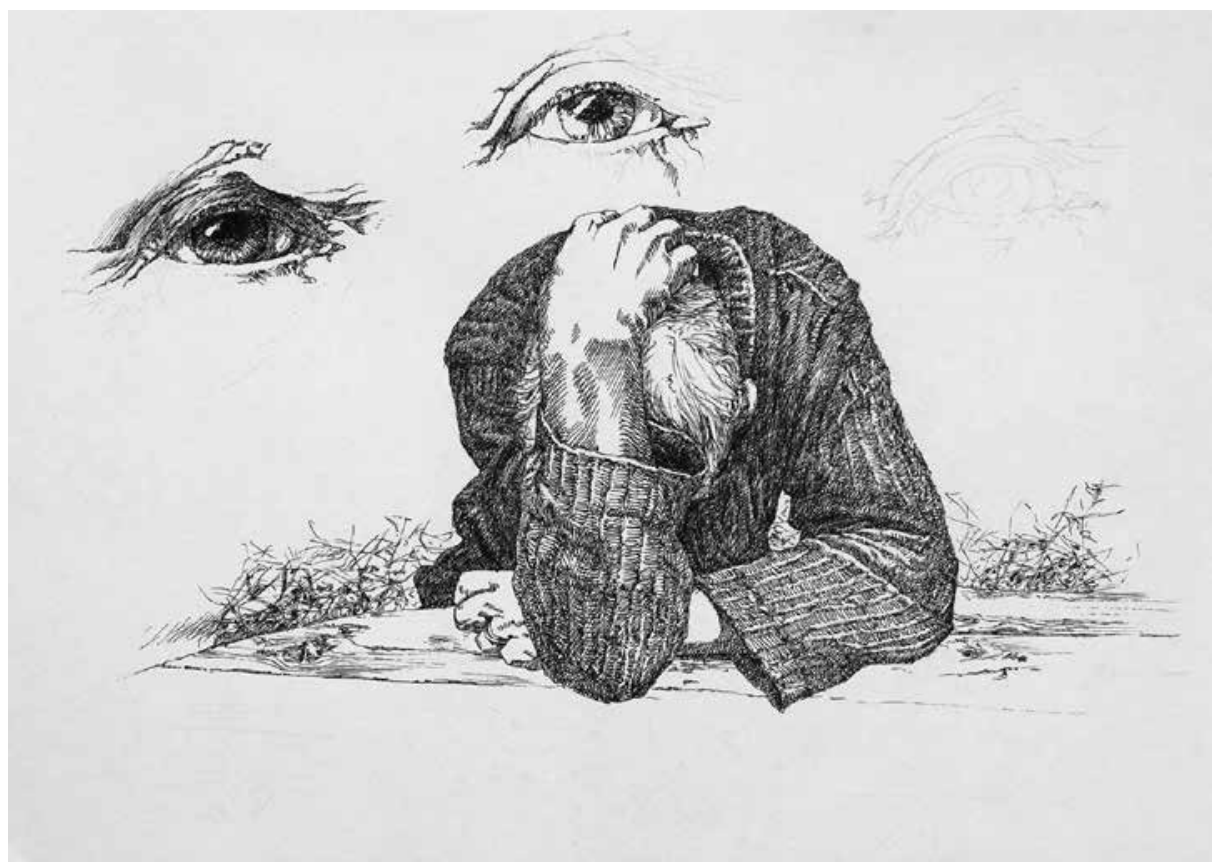

R. MULEVIČIUS. Be pavadinimo. Piešinys tušu 


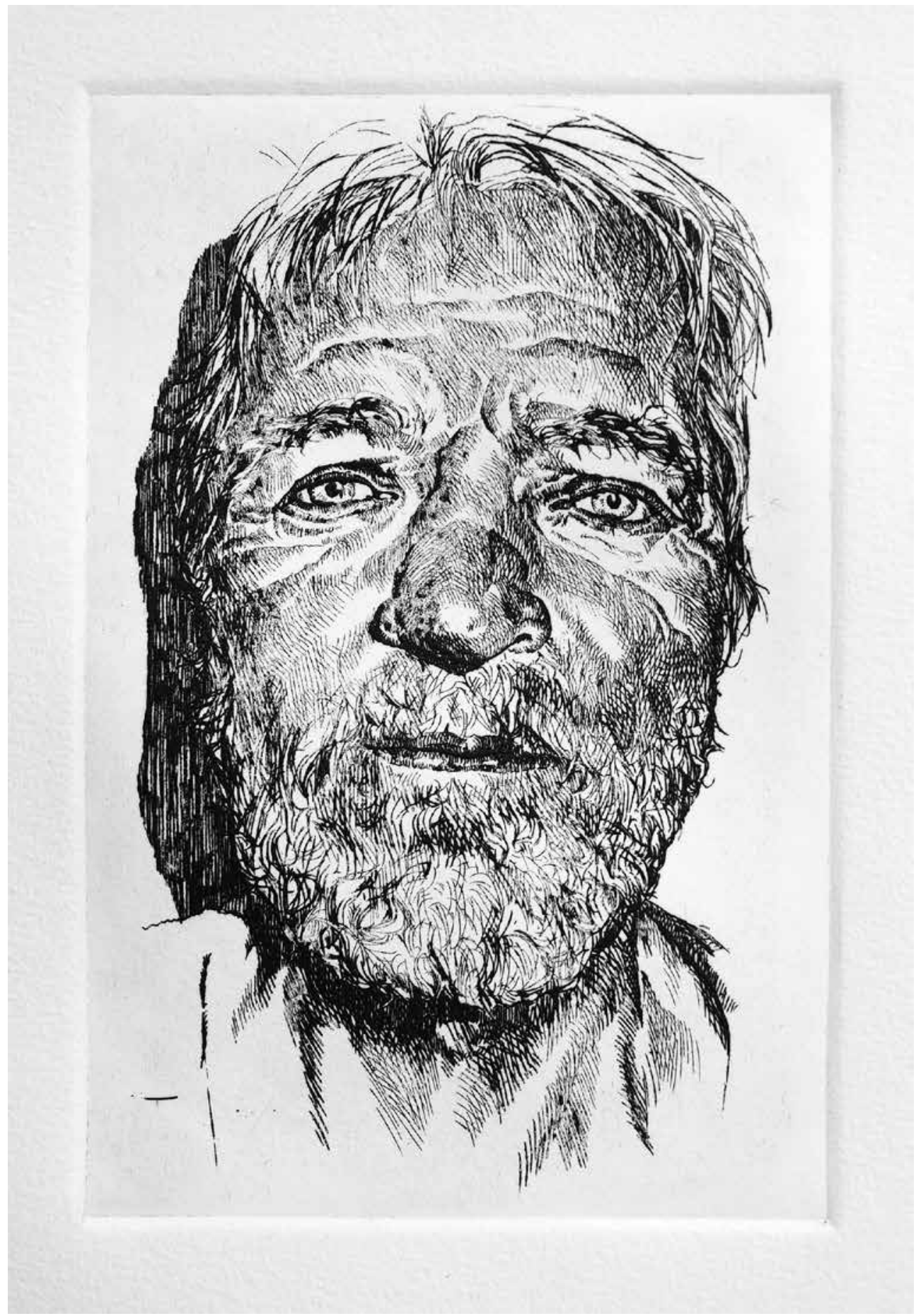

R. MULEVIČIUS. Skulptoriaus Vytauto Umbraso portretas. Estampas 